TAHKIM, Jurnal Peradaban dan Hukum Islam. Vol.1 No.2 (0ktober, 2018) ISSN : 2597-7962

\title{
KERANGKA TEORITIS DAN FILOSOFIS WAKAF UANG MELALUI PERBANKAN SYARIAH
}

\author{
Agi Sukma Gumilar \\ Pascasarjana UIN Sunan Gunung Djati Bandung \\ agisg17@gmail.com
}

\begin{abstract}
ABSTRAK
Wakaf uang atau cash waqf merupakan bagian penting dalam konsep ekonomi Islam yang dapat menunjang kemajuan dan pembangunan umat dan Negara. Pengembangan wakaf uang tidak terlepas dari kerangka teoritis dan filosofisnya sebagai dasar dalam bentuk pengembangannya khususnya perbankan syariah di Indonesia agar senantiasa berada dalam koridor hukum Islam dan hukum yang berlaku serta tetap memiliki nilai maslahah yang lebih yang dapat sesuai dengan zamannya. Penelitian ini merupakan penelitian kualitatif dengan pendekatan hukum normatif melalui studi literatur terkait wakaf uang yang berlaku di Indonesia, sehingga dapat menggali nilai-nilai dasar dari peraturan hukum yang ada terkait wakaf tersebut.
\end{abstract}

\section{Kata Kunci: Wakaf, Uang, Islam, Perbankan syariah.}

\section{ABSTRACT}

Money waqf or cash waqf is an important part of the concept of Islamic economics that can support the progress and development of the people and the State. The development of money waqf cannot be separated from its theoretical and philosophical framework as a basis in the form of its development, especially Islamic banking in Indonesia so that it is always within the corridor of Islamic law and applicable law and still has more maslahah values that can be in accordance with its time. This research is a qualitative research with a normative legal approach through literature studies related to the money waqf applicable in Indonesia, so that it can explore the basic values of the existing legal regulations related to the waqf.

Keywords: Endowments, Money, Islam, Islamic Banking. 
TAHKIM, Jurnal Peradaban dan Hukum Islam. Vol.1 No.2 (0ktober, 2018) | ISSN : 2597-7962

\section{A. PENDahuluan}

Pada dasarnya harta diciptakan untuk diambil manfaatnya. Pemanfaatan harta bisa dilakukan dengan dua cara, dengan cara menghabiskan benda tersebut atau menggunakan harta secara terus menerus dengan tetap menjaga kelanggengan benda tersebut yakni wakaf ${ }^{1}$.

Wakaf uang merupakan bagian dari ijtihad dalam bidang pengembangan potensi ekonomi Islam. Para ulama pendahulu dari Mazhab Hanafi membolehkan wakaf uang dinar dan dirham, atas dasar atsar Abdullah bin Mas'ud r.a ${ }^{2}$. Wakaf uang sudah dipraktikkan sejak awal abad kedua hijriyah, sebagaimana diriwayatkan oleh al-Bukhari bahwa Imam az-Zuhri (w. $124 \mathrm{H}$ ) memfatwakan dan menganjurkan wakaf dinar dan dirham untuk pembangunan sarana sosial, dakwah, dan pendidikan umat Islam. Beliau yang berpendapat bahwa dinar dan dirham (keduanya mata uang yang berlaku di Timur Tengah) boleh diwakafkan. Caranya ialah menjadikan dinar dan dirham itu sebagai modal usaha (dagang), kemudian menyalurkan keuntungannya sebagai wakaf ${ }^{3}$.

Wakaf uang di Indonesia seharusnya disalurkan melalui perbankan syariah ${ }^{4}$. Sehingga dengan kehadiran perbankan syariah dapat dirasakan oleh semua golongan masyarakat, baik dari masyarakat golongan menengah ke atas ataupun sebaliknya (masyarakat miskin) $^{5}$, khususnya dengan fungsi intermediasi sosial melalui adanya wakaf uang. Perbankan syariah merupakan suatu sistem yang bertujuan memberikan kontribusi positif terhadap tercapainya tujuan sosial-ekonomi dari masyarakat Muslim, sebagaimana telah terangkum dalam Maqasid al-Syariah. Sebagai suatu entitas bisnis yang bernafaskan syariah, perbankan syariah diharapkan dapat memenuhi tujuan ekonomi Islam, yakni memastikan bahwa kekayaan dapat berputar secara adil dan merata tanpa mendhalimi pihakpihak yang benar-benar berhak mendapatkannya ${ }^{6}$. Di Indonesia kini dengan tantangan

${ }^{1}$ Mushtafâ Ahmad al-Zarqâ, Ahkâm al-Awqâf, (t.tp: Dâr Ammâr, t.th), hlm. 9.

${ }^{2}$ Wahbah Az-Zuhaili, al-Fiqh al-Islami wa Adillatuh, (Bairut: Dar al-Fikr, 1985), hlm. 7612.

${ }^{3}$ Muhammad Abu Su'ud, Risalah fi Jawazi Waqf al-Nuqud, (Bairut: Dar Ibn Hazm, 1997), hlm.20-21.

${ }^{4}$ Pasal 28 Undang-undang Wakaf No.41 Tahun 2004.

${ }^{5}$ Syafii Antonio dan Hilman Fauzi Nugraha, Peran Intermediasi Sosial Perbankan Syariah Pelayanan Keuangan Bagi Masyarakat Miskin. Jurnal Keuangan dan Perbankan, Vol.16, No.2 Mei 2012, hlm. 240.

${ }^{6}$ Ibid., hlm.243.

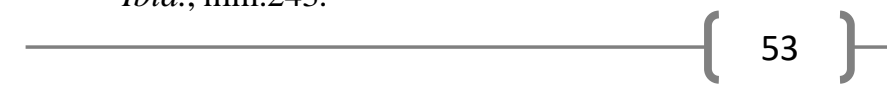


ekonomi yang terus menuntut persaingan, melahirkan dampak tingginya angka kemiskinan menurut Badan Pusat Statistik jumlah penduduk miskin dengan pengeluaran per kapita per bulan di bawah garis kemiskinan pada Maret 2016 di Indonesia mencapai 28,01 juta jiwa atau sebesar 10,86 persen dari total jumlah penduduk Indonesia ${ }^{7}$. Oleh karena itu, wakaf memainkan peran ekonomi dan sosial yang sangat penting dalam sejarah Islam ${ }^{8}$. Sehingga melalui wakaf harta dapat diakses oleh semua elemen seperti firman Allah ta'ala:

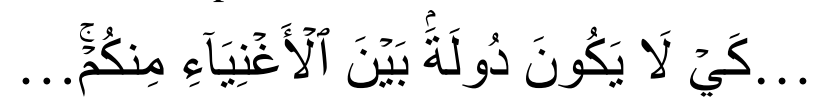

“ Supaya harta itu jangan beredar di antara orang-orang Kaya saja di antara kaти..."(Qs. Al-Hasyr:7)

Mengingat potensi wakaf sangat potensial, di tahun 2015 menurut Kepala Divisi Pengelolaan dan Pemberdayaan Wakaf Robbiyantono ${ }^{9}$ bahwa dari data yang dihimpun diketahui tanah tanah wakaf di Indonesia tercatat seluas 4,2 miliar meter persegi di 42.3000 lokasi. Selain itu, Mustafa Edwin Nasution pernah membuat asumsi bahwa penduduk muslim kelas menengah di Indonesia sebanyak 10 juta jiwa dengan penghasilan rata-rata antara 0,5 juta-10 juta perbulan, Jika warga yang berpenghasilan 2-5 juta sebanyak 2 juta orang, dan setiap tahun masing-masing mewakafkan hartanya Rp 600 ribu, maka akan tekumpul dana sebanyak 1,2 triliun. Jika warga yang berpenghasilan 5-10 juta sebanyak 1 juta orang, dan setiap tahun masing-masing mewakafkan hartanya Rp 1,2 juta, maka akan tekumpul dana sebanyak 1,2 triliun. Jadi dana yang terkumpul mencapai 3 triliun. Ini merupakan aset yang sangat potensial ${ }^{10}$. Bahkan Bank BNI Syariah di tahun 2016 berhasil menghimpun dana wakaf sebesar 2,6 Miliar hal tersebut dapat diraih dalam waktu tiga $\operatorname{tahun}^{11}$.

${ }^{7}$ http://www.spi.or.id/profil-kemiskinan-di-indonesia-2016-dalam-angka-berkurang-namun-di-desamakin-dalam-dan-parah/, diakses kamis 20 April 2017, Jam, 00.50 Wib.

${ }^{8}$ Syamsul Anwar, Studi Hukum Islam Kontemporer, (Jakarta: RM Books, 2007), hlm.75.

${ }^{9}$ www.antaranews.com. Diakses 20 April 2017, 20.00 wib.

${ }^{10}$ Departemen Agama, Fiqih Wakaf, (Jakarta: Direktorat Wakaf, 2007), hlm. 98.

${ }^{11}$ https://www.dream.co.id/dinar/bni-syariah-himpun-rp27-m-dana-wakaf-161221n.html. Diakses 10 April 2017, 08.00 wib. 
Adapun pengelolaan wakaf di Indonesia telah mengalami tiga periode besar pengelolaan wakaf yaitu pertama adalah periode tradisional dimana wakaf diperuntukkan bagi pembangunan fisik seperti masjid, pesantren dan kuburan sehingga kontribusi sosial belum begitu terasa; kedua adalah periode semi profesional dimana wakaf dikelola secara produktif namun belum dilakukan secara maksimal, sebagai contoh pembangunan masjid yang ditambah dengan bangunan toko dan gedung pertemuan untuk acara pernikahan, seminar dan lain-lain; dan ketiga, merupakan periode profesional yang ditandai dengan pemberdayaan potensi wakaf masyarakat secara produktif yang meliputi aspek: manajemen, SDM kenazhiran, pola kemitraan usaha, bentuk benda wakaf yang mulai berkembang lebih likuid seperti uang, saham dan surat berharga lainnya ${ }^{12}$.

Menurut Pasal 28 Undang-Undang Wakaf No.41 Tahun 2004 bahwa Lembaga Keuangan Syariah Sebagai Lembaga Penerima Wakaf Uang. Menurut Tholchah Hasan setelah ditetapkannya lima bank syariah sebagai Lembaga Keuangan Syariah Penerima Wakaf Uang (LKS-PWU) ${ }^{13}$ oleh Menteri Agama, menyatakan bahwa setelah ditetapkannya LKS-PWU, maka perwakafan uang harus lewat bank-bank syariah yang telah ditetapkan sebagai LKS-PWU tersebut. ${ }^{14}$.

Dipilihnya bank-bank syariah dalam menerima wakaf uang dikarenakan secara umum perbankan syariah memiliki beberapa keunggulan yang diharapkan dapat mengoptimalkan operasional wakaf uang tersebut. diantara-nya: (1) Jaringan kantor cabang yang tersebar di seluruh provinsi, kabupaten maupun kota.; (2) Kemampuan sebagai fund manager, lembaga perbankan merupakan lembaga yang memiliki pengalaman dalam mengelola dana masyarakat dan juga berpengalaman sebagai lembaga perantara surplus spending unit dengan deficit spending unit; (3) Pengalaman, jaringan informasi dan peta distribusi. Dalam praktek

${ }^{12}$ Muh. Syafii Antonio, Pengantar Pengelolaan Wakaf Secara Produktif dalam Achmad Djunaidi \& Thobieb Al-Asyhar, Menuju Era Wakaf Produktif : sebuah Upaya Progresif untuk Kesejahteraan Umat, Mitra Abadi Press, Desember, 2005.

13 Di tahun 2014 terdapat 15 LKS PWU dan 112 Nadzhir, Lihat: http://khazanah.republika.co.id/berita/dunia-islam/wakaf/14/12/02/nfy9r5-kemenag-masih-liriklirik-tetapkanlks-penerima-wakaf-uang. Diakses 20 April 2017, pukul 13.00 wib.

14 http://portal.antara.co.id/berita/1252575568/wakaf-harus-uang-melalui-bank-syariah. Diakses 20 April 2017, pukul 13.00 wib. 
operasional selanjutnya, ketiga hal tersebut menjadi faktor yang akan selalu dipertimbangkan di dalam mengoptimalkan pengelolaan dana, dan (4) Bank memiliki kredibilitas di mata masyarakat dan dikontrol dengan perundang-undangan yang berlaku. Bank syariah seharusnya merupakan lembaga yang shariah high regulated karena dipantau oleh Dewan Syariah Nasional (DSN) dan Dewan Pengawas Syariah (DPS) ${ }^{15}$. Dengan adanya pemantauan ini dapat menghindarkan bank syariah dari kesalahan pengelolaan wakaf uang.

Difungsikannya bank syariah sebagai lembaga pengelola dana wakaf merupakan manifestasi dari fungsi keharusan sebuah bank untuk mengelola tiga sektor pelanggan ekonomi, yaitu formal, nonformal dan voluntary sektor ${ }^{16}$. Hal ini terinspirasi dengan berdirinya Social Investment Bank Limited (SIBL) di Bangladesh ${ }^{17}$, yang menjalankan fungsi bank di sektor voluntary dengan menghimpun dana dari para nasabah yang kaya dalam bentuk penawaran Certificate Cash Waqf untuk program-program sosial.

Penunjukkan bank- bank syariah sebagai LKS-PWU menjadikan posisi bank-bank LKS-PWU menjadi penting dalam kesuksesan program wakaf uang. Berhasil tidaknya penghimpunan dan pengelolaan wakaf uang bergantung pada kinerja yang dilakukan oleh LKS- PWU tersebut ${ }^{18}$.

Dengan tingginya potensi wakaf uang ersebut, menjadikan semakin banyaknya ide dalam pengembangan wakaf baik secara instrumen bentuk wakaf baru maupun lembaga-lembaga penyalur wakaf baru yang akan terus berkembang dalam upaya pemberdayaan wakaf uang untuk ekonomi umat Islam di Indonesia. Oleh karena itu, penulis tertarik membuat tulisan dengan judul, “Kerangka Teoritis dan Filosofis Tentang Wakaf Uang Melalui Perbankan Syariah”.

${ }^{15}$ Biro Perbankan Syariah BI dalam Mustofa Edwin dan Uswatun Hasanah (ed.), Wakaf Tunai Inovasi Finansial Islam, Peluang dan Tantangan dalam Mewujudkan Kesejahteraan Umat, (Jakarta: PSTTI-IU, 2001), hlm. 105-106.

16 Dir. Pemberdayaan Wakaf, Strategi Pengembangan Wakaf Tunai di Indonesia, (Jakarta: Dir. Pemberdayaan Wakaf Departemen Agama, 2008), hlm. 37.

17 M.A. Mannan. Sertifikat Waqf Tunai, sebuah Inovasi Instrumen Keuangan Islam, (CIBER bekerjasama dengan PKTTI-UI), hlm. 50-51.

${ }^{18}$ Ahmad Furqon, Praktek Wakaf Tunai di Bank Syariah Mandiri, Jurnal Manahij (Jurnal Kajian Hukum Islam), Vol. IV No. 1 Januari 2012, Hlm. 114. 


\section{B. PEMBAHASAN}

\section{Pengertian Wakaf Uang}

Kata wakaf atau waqf (الوقف) berasal dari bahasa Arab yang berasal dari akar kata wa-qa-fa (وقف berarti menahan, berhenti, diam di tempat atau berdiri. Kata waqafa-yaqifuwaqfan semakna dengan kata habasa-yahbisu-tahbisan (التصرف عن احلبس (التبkanya terhalang untuk menggunakan. Kata waqf dalam bahasa Arab mengandung makna menahan, menahan harta untuk diwakafkan, tidak dipindah milikkan ${ }^{19}$.

Menurut istilah meskipun terdapat perbedaan penafsiran, disepakati bahwa makna wakaf adalah menahan dzatnya benda dan memanfaatkan hasilnya atau menahan dzatnya dan menyedekahkan manfaatnya ${ }^{20}$. Adapun perbedaan pendapat para ulama fiqh dalam mendefinisikan wakaf diakibatkan cara penafsiran dalam memandang hakikat wakaf.

Istilah lain wakaf uang adalah wakaf tunai (cash waqf atau waqf al-nuqud) merupakan salah satu wakaf benda bergerak yang dispesifikasi berupa uang ${ }^{21}$. Wakaf tunai adalah wakaf yang dilakukan seseorang, kelompok orang, lembaga atau badan hukum dalam bentuk uang tunai, termasuk dalam pengertian uang adalah surat berharga ${ }^{22}$. Wakaf tunai merupakan bentuk wakaf produktif dengan mekanisme investasi dana wakaf dan menyalurkan hasil dari pokok modal yang diinvestasikan.

\section{Dasar Hukum Wakaf Uang}

Para ahli hukum Islam menyebutkan beberapa dasar hukum wakaf berdasarkan sumber hukum Islam. Sumber hukum Islam adalah asal (tempat pengambilan) hukum Islam. Sumber hukum Islam disebut juga dengan istilah dalil hukum Islam atau pokok hukum Islam atau dasar hukum Islam yang meliputi ayat al-Qur'an, hadis, ijma', dan ijtihad ${ }^{23}$ para ahli hukum Islam serta hukum Indonesia yang mengatur tentang wakaf, yaitu sebagai berikut:

${ }^{19}$ Muhammad Ibn Bakar Ibn Mandzur Al-Mishri, Lisan Al- 'Arab, (Bulaq: Almishriyah,1301 H), Jilid 11, Hlm. 276; Wahbah Zuhaili, Al-Fiqh... Hlm, 7599.

${ }^{20}$ Abu Zahrah, Muhadharat Fi Al-Waqf, (Bairut: Dar Al-Fikr Al-'Arabi, 1971), hlm. 41.

${ }^{21}$ UU No. 41 Tahun 2004 Tentang Wakaf Pasal 28-31.

22 Fatwa Majelis Ulama Indonesia (MUI) Tentang Wakaf Uang.

${ }^{23}$ Siska Lis Sulistiani. Perbandingan Sumber Hukum Islam. Bandung: Jurnal Tahkim Fakultas Syariah UNISBA, Vol.1 No. 1, 2018, hlm. 103.

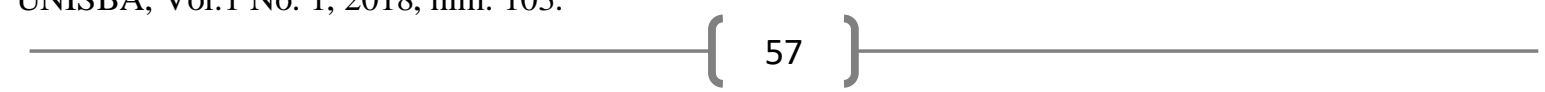




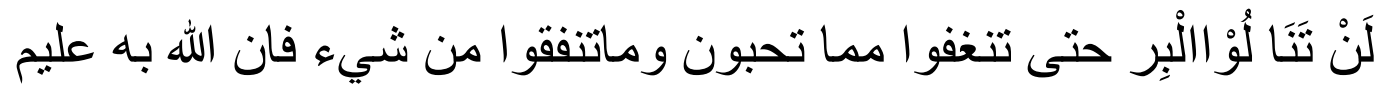

Kamu sekali-kali tidak sampai kepada kebajikan (yang sempurna), sebelum kamu menafkahkan sebagian harta yang kamu cintai. Dan apa saja yang kamu nafkahkan Maka Sesungguhnya Allah mengetahuinya”. (QS. Ali Imran [3]: 92).

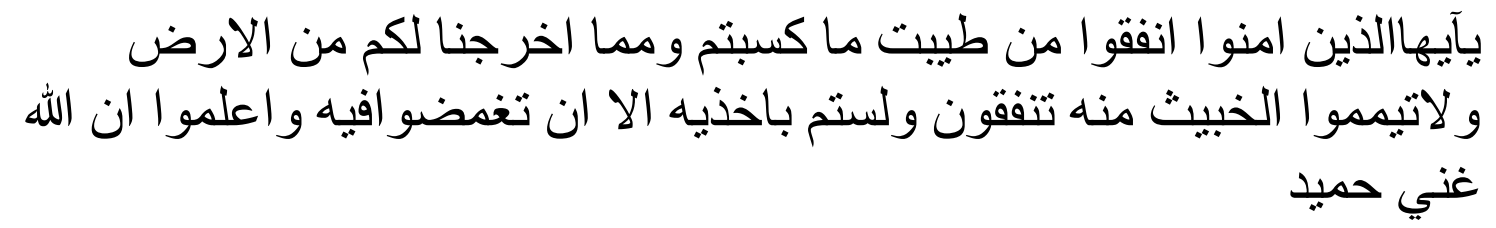

Wahai orang-orang yang beriman, infakkanlah sebagian dari hasil usahamu yang baik, dan dari apa yang kamu keluarkan untuk dari alam bumi. Dan janganlah kamu memilih yang buruk-buruk daripadanya untuk kemudian kamu infakkan padahal kamu sendiri tidak mau mengambilnya kecuali dengan memicingkan mata (enggan). Ketahuilah bahwa Allah Maha Kaya lagi Maha Terpuji. (QS. Al-Baqarah [2]: 267).

Dalam Al-qur'an tidak ditemukan secara explisit dan tegas mengenai wakaf, Alqur'an hanya menyebutkan dalam artian umum saja, tidak tegas dan khusus menggunakan kata-kata wakaf. Para fuqaha menjadikan ayat-ayat umum itu sebagai dasar wakaf dalam Islam. Seperti ayat-ayat yang membicarakan sedekah, infak dan amal jariyah. Para ulama menafsirkannya bahwa wakaf itu sudah tercakup di dalam cakupan ayat tersebut ${ }^{24}$.

Mayoritas ulama menyatakan asal mula disyari'atkannya ibadah wakaf dalam Islam adalah pada periode Rasulullah SAW, di mana ketika itu Umar bin Khattab mendapat sebidang tanah di Khaibar $^{25}$. sebagaimana hadis berikut:

Dari Ibnu Umur r.a. (dilaporkan) bahwa 'Umar Ibn al-Khattab memperoleh sebidang tanah di Khaibar, lalu beliau datang kepada Nabi Saw untuk minta instruksi beliau tentang tanah tersebut. Katanya: Wahai Rasulullah, saya memperoleh sebidang tanah di Khaibar yang selama ini belum pernah saya peroleh harta yang lebih berharga dari saya dari padanya. Apa instruksimu mengenai harta itu? Rasulullah bersabda: Jika engkau mau, eng kau dapat menahan pokoknya (melembagakan bendanya) dan menyedekahkan manfaatnya. [Ibnu Umar lebih lanjut] melaporkan: Maka Umar menyedekahkan tanah itu dengan ketentuan tidak boleh dijual, dihibahkan atau diwariskan. Ibnu Umar berkata: Umar menyedekahkankannya kepada orang fakir, kaum kerabat, bidak belian, sabilillah, ibn sabil dan tamu. Dan tidak dilarang bagi orang yang menguasai tanah wakaf itu (mengurus) untuk

${ }^{24}$ Abdul Halim, Hukum Perwakafan di Indonesia, (Jakarta:Ciputat press, 2005), hlm. 49.

${ }^{25}$ Syaikh Muhammad bin Shalih al-Usman, Panduan Wakaf, Hibah, dan Wasiat Menurut alQur"an dan as-Sunnah, (Jakarta:Pustaka Imam Syafi`I, 2008), hlm.7. 
makan dari hasilnya dengan cara baik (sepantasnya) atau makan dengan tidak bermaksud menumpuk harta. [HR Bukhari] ${ }^{26}$.

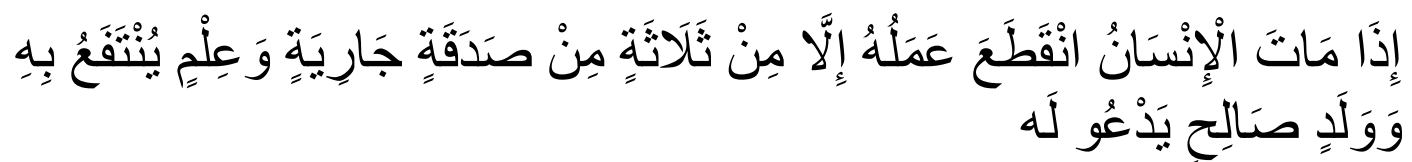

Dari Abu Hurairah r.a. (dilaporkan bahwa Rasulullah saw bersabda: Apabila seseorang meninggal dunia, maka putuslah amalnya kecuali tiga hal: sedekah yang mengalir, ilmu yang di manfaatkan atau anak salih yang mendo'akannya. [HR. Muslim] ${ }^{27}$.

Sedekah jariyah yang disebutkan dalam hadis Abu Hurairah tidak lain yang dimaksud adalah wakaf, dimana pokok bendanya tetap, sedangkan manfaat benda yang diwakafkan itu mengalir terus sehingga wakif (pelaku wakaf) tetap mendapat pahala atas amalnya meskipun ia telah meninggal dunia ${ }^{28}$.

Selain dasar dari al-Qur'an dan hadis di atas, para ulama sepakat (ijma') menerima wakaf sebagai suatu amal jariyah yang disyari'atkan dalam Islam. Tidak ada orang yang dapat menafikan dan menolak amalan wakaf dalam Islam karena telah menjadi amalan yang senantiasa dijalankan dan diamalkan oleh para sahabat Nabi dan kaum muslimin sejak masa awal Islam hingga sekarang ${ }^{29}$.

Ketentuan-ketentuan detail mengenai perwakafan didasarkan kepada ijtihad para ahli hukum Islam. Seperti: pendapat Imam al-Zuhri (w. 124 H.) bahwa mewakafkan dinar hukumnya boleh, dengan cara menjadikan dinar tersebut sebagai modal usaha kemudian keuntungannya disalurkan pada mauquf alaih $^{30}$, serta fatwa Majelis Ulama Indonesia tentang wakaf uang tahun 2002.

${ }^{26}$ Muslim, Shahih Muslim, (Mesir: Dar al-Fikr al-Mu’ashir, t.t), Juz 8, Hlm. 407.

${ }^{27}$ Ibid, Hlm. 405.

${ }^{28}$ Syamsul Anwar, Studi Hukum.., hlm. 79.

${ }^{29}$ Andri Soemitra, Bank \& Lembaga Keuangan Syariah, cet ke-2, (Jakarta: Kencana, 2010), hlm. 435 436.

${ }^{30}$ Abu Su'ud Muhammad, Risalah fi Jawazi Waqf al- Nuqud, (Beirut: Dar Ibn Hazm, 1997), hlm. 2021. 
Dalam hukum Indonesia sumber-sumber pengaturan wakaf antara lain meliputi PP No. 28 Tahun 1977 tentang Perwakafan Tanah Milik, Permendagri No. 6 Tahun 1977 tentang Tata Pendaftaran Tanah mengenai Perwakafan Tanah Milik, Permenag No. 1 Tahun 1978 tentang Peraturan Pelaksanaan PP No. 28 Tahun 1977 tentang Perwakafan Tanah Milik, dan berbagai surat keputusan Menag dan Dirjen Binbaga Islam Departemen Agama, serta Kompilasi Hukum Islam di Indonesia (KHI). Yang lebih penting di atas semua itu adalah Undang-Undang Nomor 41 Tahun 2004 tentang Perwakafan. Dalam pasal 70 ditegaskan bahwa semua peraturan perundang-undangan yang mengatur mengenai perwakafan masih tetap berlaku sepanjang tidak bertentangan dan/atau belum diganti dengan peraturan yang baru berdasarkan Undang-Undang ini $^{31}$.

Pada tanggal 11 Mei 2002 Komisi Fatwa Majelis Ulama Indonesia telah menetapkan fatwa tentang wakaf uang, yang isinya adalah sebagai berikut.

a. Wakaf uang (Cash Wakaf/Waqf al-Nuqud) adalah wakaf yang dilakukan seseorang, kelompok orang, lembaga atau badan hukum dalam bentuk uang tunai.

b. Termasuk ke dalam pengertian uang adalah surat-surat berharga.

c. Wakaf uang hukumnya jawaz (boleh).

d. Wakaf uang hanya boleh disalurkan dan digunakan untuk hal-hal yang dibolehkan secara syar'i.

e. Nilai pokok wakaf uang harus dijamin kelestariannya, tidak boleh dijual, dihibahkan, dan atau diwariskan.

Dengan demikian, intinya wakaf uang atau kadang disebut dengan wakaf tunai adalah wakaf berupa uang dalam bentuk rupiah yang dapat dikelola secara produktif, hasilnya dimanfaatkan untuk mauquf 'alaih. Ini berarti bahwa uang yang diwakafkan tidak boleh diberikan langsung kepada mauquf 'alaih, tetapi nazhir harus menginvestasikan lebih dulu, kemudian hasil investasi itulah yang diberikan kepada mauquf 'alaih.

${ }^{31}$ Siska Lis Sulistiani. Pembaruan Hukum Wakaf di Indonesia. (Bandung: Refika Aditama, 2017), hlm. 20. 
TAHKIM, Jurnal Peradaban dan Hukum Islam. Vol.1 No.2 (0ktober, 2018) ISSN : 2597-7962

\section{Manfaat Wakaf Uang}

Ada empat manfaat utama dari wakaf uang dewasa ini, yaitu sebagai berikut:

a. Wakaf uang jumlahnya bisa bervariasi sehingga seseorang yang memiliki dana terbatas sudah bisa mulai memberikan dana wakafnya tanpa harus menunggu menjadi tuan tanah terlebih dahulu.

b. Melalui wakaf tunai, asset wakaf yang berupa tanah-tanah kosong dapat dimanfaatkan untuk pembangunan gedung atau diolah lahan pertanian.

c. Dana wakaf tunai juga bisa membantu sebagai lembaga pendidikan Islam yang cash flownya terkadang kembang kempis dan menggaji civitas akademika ala kadarnya.

d. Pada gilirannya umat Islam dapat lebih mandiri dalam mengembangkan dunai pendidikan tanpa harus selalu tergantung pada anggaran pendidikan negara yang terbatas $^{32}$.

Wakaf uang membuka peluang yang unik untuk menciptakan investasi guna memberikan pelayanan keagamaan, layanan pendidikan, dan layanan sosial. Tabungan orang-orang kaya dapat dimanfaatkan dengan menukarkannya dengan Cash-Waqf Certificate. Hasil pengembangan wakaf yang diperoleh dari sertifikat tersebut dapat dimanfaatkan untuk tujuan-tujuan yang bermacam-macam seperti tujuan-tujuan wakaf itu sendiri. Kegunaan lain dari Cash-Waqf Certificate adalah bahwa dia dapat mengubah kebiasaan lama di mana kesempatan wakaf seolah-olah hanya untuk orang-orang kaya saja ${ }^{33}$.

\section{Pengertian Perbankan Syariah}

Perbankan syariah adalah suatu sistem perbankan yang dikembangkan berdasarkan prinsip syariah, yaitu segala ketentuan yang mengacu dan berdasarkan pada hukum Islam ${ }^{34}$. Hukum Islam yang disepakati para ulama mengacu pada sumbernya yaitu Al-Qur'an, sunnah, ijma dan qiyas.

\footnotetext{
32 Syafii Antonio, Cash Waqf dan Anggaran Pendidikan, dalam Kumpulan Hasil Seminar Perwakafan, (Jakarta: Depag RI, 2004), hlm. 212.

${ }^{33}$ Syafrudin Arif, Wakaf Tunai, Jurnal La Riba Ekonomi Islam, Vol.IV, No.1 Juli, ,Yogyakarta: UII, 2010, hlm. 103.

${ }^{34}$ Burhanuddin Susanto, Hukum Perbankan Syariah Di Indonesia, (Yogyakarta: UII Press, 2008), hlm, 13 .
}

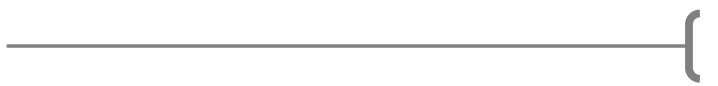

61 
Adapun pengertian bank Islam (Islamic Bank) secara umum adalah bank yang pengoperasiannya mendasarkan pada prinsip syariah Islam. Istilah-istilah lain yang digunakan untuk menyebut entitas Bank Islam selain Bank Islam itu sendiri, yaitu bank Tanpa Bunga (Interest-Free Bank), Bank Tanpa Riba (Lariba Bank), dan bank Syariah (Sharia Bank). Indonesia secara teknis yuridis menyebut Bank Islam dengan mempergunakan istilah "Bank Syariah", atau yang secara lengkap disebut "bank berdasarkan prinsip syariah" 35 . Prinsip-prinsip syariah merupakan segala ketentuan yang berlandaskan pada sumber hukum tersebut. Untuk dapat mengimplementasikan prinsip-prinsip dasar sehungga dapat diterapkan secara lebih pragmatis, dilakukan perumusan aturan teknis, termasuk di dalamnya aturan yang dibuat oleh lembaga berwenang dalam sistem hukum negara tertentu ke dalam bentuk peraturan hukum yang bersifat amaliah ${ }^{36}$. Pada umumnya lembaga keuangan dalam hal ini lembaga keuangan syariah merupakan lembaga perantara dari pihak yang memiliki kelebihan dana (surplus of funds) dengan pihak yang kekurangan dana (lack of funds), memiliki fungsi sebagai perantara keuangan masyarakat(financial intermediary) ${ }^{37}$.

Meski demikian harus diakui istilah "sistem perbankan dan keuangan Islam" relatif baru. Mulai ramai didiskusikan sejak pertengahan 1980-an. Dalam konsepsi Islam aktivitas komersial, jasa dan perdagangan harus disesuaikan dengan prinsip Islam diantaranya "bebas bunga". Hal inilah yang juga menjelaskan mengapa pada tahap awal bank Islam atau bank syariah juga dikenal sebagai bank bebas bunga. Meski demikian mengambarkan sistem perbankan Islam secara sederhana hanya "bebas bunga" tidak menghasilkan suatu gambaran yang benar atas sistem ini secara keseluruhan. Memang benar bahwa dalam perbankan Islam, melarang menerima dan membayar bunga menjadi inti (nucleus) dari sistem. Tetapi

35 Peri Umar Farouk, Sejarah Hukum Perbankan Syariah Indonesia, Dikutip Dari Http://Www.Sharialearn.Com/ diakses 19 November 2016.

${ }^{36}$ Burhanudin Susanto. Hukum Perbankan.... hlm. 13.

${ }^{37}$ Muchdarsyah Sinungan, Uang Dan Bank, (Jakarta: Bina Aksara, 1987), hlm. 111.

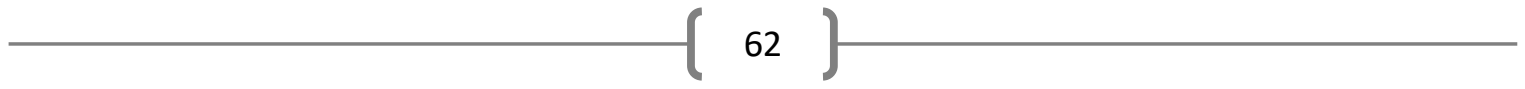


perbankan Islam idealnya juga didukung oleh prinsip-prinsip Islam sepeti konsep; berbagi resiko, hak dan kewajiban individu, hak milik, dan kesucian akad (kontrak). ${ }^{38}$

\section{Dasar Hukum Perbankan Syariah}

Sebagai lembaga keuangan publik, keberadaan perbankan syariah secara legal state dan yuridis normatif ditopang oleh regulasi pemerintah berupa Undang-undang nomor 7 tahun 1992 tentang Perbankan, Undang-undang nomor 10 tentang Perubahan atas Undangundang nomor 7 tahun 1998 tentang Perbankan, Undang-undang nomor 3 tahun 2004 Tentang Perubahan atas Undang-undang nomor 23 tahun 1999 tentang Bank Indonesia, Undang-undang nomor 3 tahun 2006 tentang Perubahan atas Undang-undang nomor 7 tahun 1989 tentang Peradilan Agama. Selain itu, secara yuridis empiris keberadaan perbankan syariah di Indonesia semakin diakui eksistensinya. Hal ini dapat dilihat dengan tumbuh dan perkembangannya yang secara umum telah mencakup wilayah setiap propinsi dan kabupaten di Indonesia ${ }^{39}$, Undang-undang nomor 23 tahun 2003, Undang-undang nomor 21 tahun 2008.

Bahkan sebagai lembaga keuangan yang mengacu pada ideologi Islam, perbankan syariah dalam operasionalnya juga langsung merujuk pada sumber hukum Islam utama yaitu al Qur'an sebagaimana dalam surat al Baqarah ayat 275:

"Orang-orang yang makan (mengambil) riba tidak dapat berdiri melainkan seperti berdirinya orang yang kemasukan syaitan lantaran (tekanan) penyakit gila Keadaan mereka yang demikian itu, adalah disebabkan mereka berkata (berpendapat), sesungguhnya jual beli itu sama dengan riba, padahal Allah telah menghalalkan jual beli dan mengharamkan riba. Orang-orang yang telah sampai kepadanya larangan dari Tuhannya, lalu terus berhenti (dari mengambil riba), maka baginya apa yang telah diambilnya dahulu (sebelum datang larangan); dan urusannya (terserah) kepada Allah. Orang yang kembali (mengambil riba), maka orang itu adalah penghuni-penghuni neraka; mereka kekal di dalamnya. (Q.S. al Baqarah [2] : 275)

${ }^{38}$ M. Umer Capra \& Habib Ahmed, Corporate Governance In Islamic Financial Institution, (Jedah: Ocasional Paper IDB, 2002), hlm. 1.

39 Zainuddin Ali, Hukum Perbankan Syariah, (Jakarta: Sinar Grafika, 2008), hlm. 2. 


\section{Fungsi dan Peran Perbankan Syariah}

Pada tanggal 17 Juni 2008 telah disahkan Undang-Undang Perbankan Syariah yang pengundangannya dalam Lembaran Negara dilakukan tanggal 16 Juli 2008, yakni UndangUndang Nomor 21 Tahun 2008 tentang Perbankan Syariah. Undang-undang dimaksud memperkenalkan beberapa muatan baru dan lembaga hukum baru yang ditujukan untuk menunjang pelaksanaan pembangunan nasional dalam rangka meningkatkan keadilan, kebersamaan, dan pemerataan kesejahteraan rakyat ${ }^{40}$.

Perbankan dalam kehidupan suatu negara adalah salah satu agen pembangunan (agent of development). Hal ini dikarenakan adanya fungsi utama dari perbankan yaitu sebagai lembaga yang menghimpun dana dari masyarakat dalam bentuk simpanan dan menyalurkan kembali dalam bentuk kredit atau pembiyaan. Fungsi ini lazim disebut sebagai intermediasi keuangan (financial intermediary function) yang diharapkan menjadi jembatan kemajuan ekonomi dan pembangunan nasional Indonesia ${ }^{41}$.

Realisasi dari tujuan dimaksud, terwujud dalam fungsi bank syariah dan UUS yaitu bahwa: (1) Bank Syariah dan UUS wajib menjalankan fungsi menghimpun dan menyalurkan dana masyarakat; (2) Bank Syariah dan UUS dapat menjalankan fungsi sosial dalam bentuk baitul mal, yaitu menerima dana yang berasal dari zakat, infak, sedekah, hibah, atau dana sosial lainnya dan menyalurkannya kepada organisasi pengelola zakat; (3) Bank Syariah dan UUS dapat menghimpun dana sosial yang berasal dari wakaf uang dan menyalurkannya kepada pengelola wakaf (nazhir) sesuai dengan kehendak pemberi wakaf (wakif) ${ }^{42}$. Pelaksanaan fungsi sosial mendasarkan pada peraturan perundang-undangan terkait, yakni Undang-Undang Nomor 38 Tahun 1999 tentang Pengelolaan Zakat dan Undang-Undang Nomor 41 Tahun 2004 tentang Wakaf. Hal inilah yang menunjukkan bahwa perbankan syariah berperan sebagai financial and social intermediaries institution.

40 Pasal 3 UU No. 21 Tahun 2008.

${ }^{41}$ Abdul Ghofur Anshori, Perkembangan Hukum Perbankan di Indonesia, Makalah pada kuliah perdana mahasiswa MKn UGM, dalam Kapita Selekta Perbankan Syariah di Indonesia, Yogyakarta: UII Press, 2006, hlm. 1.

42 Pasal 4 UU No. 21 Tahun 2008 


\section{Wakaf Uang melalui Perbankan Syariah}

Terkait dengan pengelolaan wakaf, menurut Mustafa Ahmad al-Zarqa’, permasalahan wakaf merupakan permasalahan ijtihadiyah, sehingga pertimbangan rasio dan kemaslahatan dapat dipergunakan dalam pengelolaan wakaf $^{43}$. Penunjukan LKS-PWU sebagai lembaga penerima wakaf uang merupakan bentuk ijtihad berbasis maslahah almursalah, karena tidak ada dalil-dalil atau nash-nash sarih yang menyetujui ataupun menolaknya, akan tetapi masuk dalam keumumaan tujuan disyariatkannya hukum-hukum Islam, diantaranya adalah dalam rangka menjaga harta (hifz al-mal), terutama harta wakaf agar dapat terjamin kelestariannya $^{44}$.

Pada masa awal, lembaga keuangan yang menggunakan instrumen syariah banyak bergerak pada pelayanan bagi masyarakat miskin pedesaan. Seperti halnya Mit Ghamr di Mesir yang mem fokuskan diri pada pembangunan ekonomi, pengentasan kemiskinan, pembelajaran budaya hidup hemat di kalangan masyarakat muslim yang miskin. Akan tetapi, seiring dengan perkembangan zaman, orientasi dari lembaga keuangan syariah (termasuk perbankan syariah) lebih didominasi pada doktrin mengejar keuntungan yang tinggi (High Profit Maximization Doctrine). Pada akhirnya pergerakan lembaga keuangan syariah hanya dapat memberikan pelayanan bagi masyarakat kaya, sementara itu masyarakat miskin yang tidak memiliki pemahaman tentang lembaga keuangan bank tidak pernah diikutsertakan, padahal mereka mayoritas muslim. Fenomena tersebut seutuhnya tidak merefleksikan alasan utama perbankan syariah sebagai lembaga yang berbasis pada syariah yang seharusnya mencerminkan identitas dan nilai-nilai Islam ${ }^{45}$.

Dalam tradisi Islam, dua model dasar yang dapat diaplikasikan oleh perbankan syariah untuk memberdayakan masyarakat miskin ialah pendekatan sosial (tabarru' approach) dan pendekatan komersial (tijari approach) yang mengandung pemberdayaan edukatif. Dalam model ini penanaman elemen-elemen edukatif sangat ditekankan, termasuk juga pembentukan karakter sebagai modal sosial untuk menjadi enterpreneur yang baik, yang

\footnotetext{
${ }^{43}$ Ahmad Zarqa, Ahkam ..., Hlm. 2

${ }^{44}$ Ahmad Furqon, Praktek Wakaf..., hlm. 115.

45 Ibid, hlm.133.
}

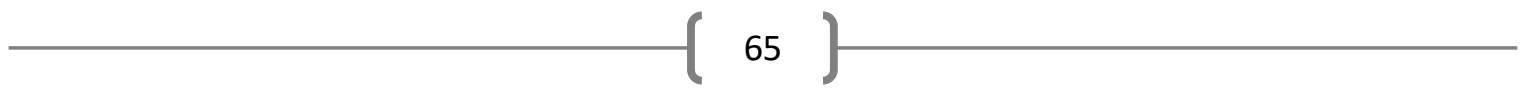


selanjutnya menjadi Muzakki, ini disebut dengan pendekatan sosial (tabarru' approach). Sedangkan, memberikan kesempatan secara langsung kepada masyarakat miskin untuk dapat memperoleh jasa keuangan disebut aqd tijari (tijari approach). Dalam pengertian yang lebih sederhana, dua model pendekatan di atas merupakan nilai-nilai yang ada dalam program intermediasi sosial. Ada proses edukasi ketika masyarakat mendapatkan dana tabarru' untuk kemudian diproyeksikan untuk mendapatkan dana tijari (akad komersil)· Akan tetapi, kedua model pendekatan di atas hanya dapat relevan dan berjalan dengan optimal jika data terkait keberadaan masyarakat miskin diolah dengan baik dan dapat dipertanggungjawabkan. ${ }^{46}$..

Di Indonesia wakaf tunai memiliki undang-undang khusus yang mengatur tentang pengertian dan mekanismenya yaitu Undang-undang Nomor 41 tahun 2004 tentang Wakaf. Untuk melengkapi undang-undang tersebut, pemerintah juga telah menetapkan Peraturan Pemerintah Nomor 42 tahun 2006 tentang Pelaksanaan Undang-undang Nomor 41 tahun 2004.

Sebelum itu, telah ada berbagai peraturan yang mengatur tentang wakaf ${ }^{47}$. Peraturan yang mengatur tentang wakaf adalah;

a. UU No. 5 Tahun 1960 tentang Peraturan Dasar Pokok-pokok Agraria, khususnya pasal 5, 14 (1), dan 49,

b. PP No. 28 Tahun 1977 tentang Perwakafan Tanah Milik, Peraturan Menteri No. 1 Tahun 1978 tentang Peraturan Pelaksanaan PP No. 28 Tahun 1977,

c. Intruksi Bersama Menag RI dan Kepala BPN No. 4 Tahun 1990 tentang Sertifikat Tanah Wakaf, Badan Pertanahan Nasional No. 630.1-2782 tantang Pelaksanaan Penyertifikatan Tanah Wakaf,

d. Inpres No. 1 Tahun 1991 tentang KHI, SK Direktorat BI No. 32/34/KEP/DIR tentang Bank Umum Berdasarkan Prinsip Syariah (pasal 29 ayat 2 berbunyi: bank dapat bertindak sebagai lembaga baitul mal, yaitu menerim dana yang berasal dari

${ }^{46}$ Marquerite S Robinson, Beberapa Strategi Yang Berhasil Untuk Mengembangkan Bank Pedesaan: Pengalaman Dengan Bank Rakyat Indonesia (BRI) 1970-1990, (Jakarta: Institut Bankir Indonesia, 1993), hlm, 28.

${ }^{47}$ Lihat; DEPAG RI, Peraturan Perundangan Perwakafan. (Jakarta: DEPAG RI, 2006) 
zakat, infaq, shadaqah, wakaf, hibah, atau dana sosial lainnya dan menyalurkannya kepada yang berhak dalam bentuk santunan dan atau pinjaman kebajikan [qard alhasan]),

e. SK Direktorat BI No. 32/36/KEP/DIR tentang Bank Perkreditan Rakyat Berdasarkan Prinsip Syariah (pasal 28 berbunyi: BPRS dapat bertindak sebagai lembaga baitul mal, yaitu menerim dana yang berasal dari zakat, infaq, shadaqah, wakaf, hibah, atau dana social lainnya dan menyalurkannya kepada yang berhak dalam bentuk santunan dan atau pinjaman kebajikan [qard al-hasan] ${ }^{48}$.

Beberapa aspek penting lain dalam UU Perbankan Syariah nampak sudah berada pada arah yang tepat, antara lain ${ }^{49}$ :

a. Ketentuan bahwa bank konvensional dapat dikonversi menjadi bank syariah dan larangan bank syariah dan BPRS dikonversi menjadi bank konvensional atau BPR;

b. Mengizinkan kepemilikan asing secara kemitraan dengan investor domestik;

c. Mendorong spin-off UUS menjadi Bank Umum Syariah (BUS) secara smooth yaitu ketika aset UUS telah mencapai 50\% dari induknya atau 15 tahun setelah berlakunya UU Perbankan Syariah;

d. Dalam hal terjadi merger atau konsolidasi bank syariah dengan bank lain, maka bank hasil merger atau konsolidasi harus menjadi bank syariah;

e. Dana zakat dan sosial yang dihimpun perbankan syariah harus disalurkan ke organisasi pengelola zakat;

f. Bank syariah dapat menghimpun wakaf uang;

g. Penegasan dan landasan yang kuat untuk BPR Syariah; dan

h. Kewajiban tata kelola yang baik

Di point ke enam selain usaha komersial, bank syariah dapat pula menjalankan fungsi sosial dalam bentuk: lembaga baitul mal, yaitu menerima dana yang berasal dari zakat, infak, sedekah, hibah, atau dana sosial lainnya dan menyalurkannya kepada organisasi penelola

${ }^{48}$ Elsi Kartika Sari, Pengantar Hukum Zakat dan Wakaf. (Jakarta: Grasindo, 2006), hlm. 57-59.

49 Aam Slamet Rusydiana, Mencandera Industri Perbankan Syariah Indonesia: Tinjauan Kritis Pasca UU 21 Tahun 2008, Jurnal Ekonomi Islam La Riba, Vol. II, No. 2, Desember 2008. 
zakat (Pasal 4 ayat 2); dan menghimpun dana sosial dari wakaf uang dan menyalurkannya kepada lembaga pengelola wakaf (nazhir) sesuai kehendak pemberi wakaf (wakif) (Pasal 4 ayat 3$)$.

Hubungan keuangan bagi masyarakat miskin dengan perbankan syariah melalui proses intermediasi sosial yang seharusnya memegang tanggung jawab lebih besar terhadap kesejahteraan sosial dan komitmen religius demi tercapainya tujuan ekonomi Islam, termasuk juga keadilan sosial, distribusi pendapatan/kekayaan yang merata, dan meningkatkan pertumbuhan ekonomi ${ }^{50}$.

Gambar 1

\section{Peran Perbankan Syariah dalam bidang sosial}

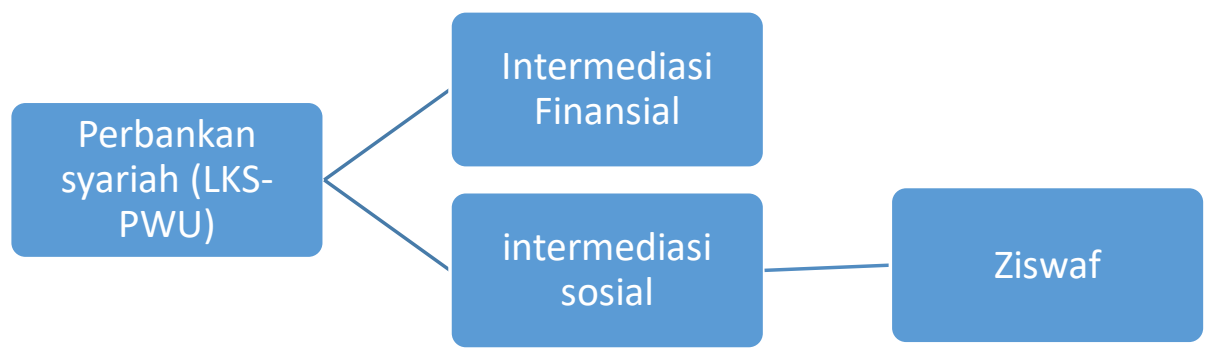

Peran perbankan syarian sebagai penyalur wakaf tunai (cash waqf atau waqf alnuqud), yaitu wakaf yang dilakukan seseorang, kelompok orang, lembaga atau badan hukum dalam bentuk uang tunai. Termasuk ke dalam pengertian uang adalah surat-surat berharga. Terdapat beberapa aturan dalam wakaf benda bergerak berupa uang (wakaf tunai) antara lain:

a. Wakaf tunai melalui lembaga keuangan syariah yang ditunjuk oleh Menteri

b. Pernyataan kehendak wakif tentang wakaf tunai harus tertulis

c. Lembaga keuangan syariah menerbitkan sertifikat wakaf uang yang disampaikan kepada wakif dan nadzir sebagai bukti penyerahan harta benda wakaf.

d. Lembaga keuangan syariah atas nama nadzir mendaftarkan benda wakaf berupa uang kepada Menteri

${ }^{50}$ Syafii Antonia Dan Hilman F Nugraha, Peran Intermediasi Sosial Perbankan Syariah Pelayanan Keuangan Bagi Masyarakat Miskin. Jurnal Keuangan dan Perbankan, Vol.16, No.2 Mei, 2012, hlm, 132. 
Adapun nadzir hanya Lembaga Keuangan Syariah berdasarkan UU No. 41 tahun 2004, bahwa untuk kasus wakaf tunai nadzir yang diberi wewenang untuk mengelola adalah lembaga keuangan syariah yang ditunjuk oleh menteri ${ }^{51}$. Pemerintah menyatakan bahwa pengelolaan wakaf tunai melalu lembaga keuangan syariah ini atas dasar pertimbangan keuangan. Mestinya penyerahan dan pengelolaan wakaf tunia tak hanya diserahkan kepada lembaga keuangan syariah, karena ada lembaga lain yang mampu mengelola wakaf tunai tersebut dengan profesional dan diyakini mampu menjaga keamanan wakaf. Ada dua hal yang dicermati dari penyerahan dan pengelolaan wakaf tunai oleh lembaga keuangan syariah, yaitu:

a. Lembaga keuangan syariah adalah lembaga profit dan komersial, ia juga harus memikirkan pendayagunaan sosial wakaf, yang ditakutkan adalah dana wakaf tersebut justru menyokong kegiatan komersialnya sendiri, sehingga bahwa wakaf itu harus diberikan manfaat ekonomi bagi umat, dan

b. Tereduksinya peran dan pemberdayaan masyarakat dalam hal-hal produktif, sementara intinya adalah kapabilitas, kredibilitas, profesionalitas dari nadzir, bukan status nadzir yang akan mengelola wakaf tunai ${ }^{52}$.

\section{SIMPULAN}

Peran filsafat hukum dalam bidang pengembangan wakaf tunai di Indonesia sangat penting tanpa perannya tidak akan ada landasan yuridis yang kuat , untuk memayungi setiap gerak dan langkah dalam mengembangkan pengembangan wakaf khususnya di sektor perbankan syariah. Dengan adanya UU No.41 tahun 2004 menjadi bagian sebuah legalisasi wakaf untuk memberikan nilai kesejahteraan untuk masyarakat luas dalam rangka hifzu maal menjaga harta kaum muslimin dan menjaga kaum muslimin lainnya dari kefakiran. Disertai teori yang berkembang seperti kepastian hukum dalam teori pemberlakuan hukum Islam di Indonesia turut memberikan kontribusi secara hukum terhadap praktif wakaf di Indonesia.

51 UU No. 41 Tahun 2004 Tentang Wakaf Pasal 28. Syariah”.

52 Republika, Jum'at, 01 Oktober 2004, “Pengelolaan Wakaf Tunai Hanya Oleh Lembaga Keuangan 
TAHKIM, Jurnal Peradaban dan Hukum Islam. Vol.1 No.2 (0ktober, 2018) | ISSN : 2597-7962

Adapun saran dari penulis agar para akademisi dan para ulama dapat bersinergis dalam membentuk aturan-aturan yang lebih maslahat untuk kemajuan ekonomi Umat.

\section{DAFTAR PUSTAKA}

Al-Zarqâ, M. A. T.th. Ahkâm al-Awqâf. t.tp: Dâr Ammâr.

Ali, Z. (2008). Hukum Perbankan Syariah, Jakarta: Sinar Grafika

Anwar, S. (2007). Studi Hukum Islam Kontemporer. Jakarta: RM Books.

Al-Mishri, M. (1301). Lisan Al-'Arab. Bulaq: Almishriyah.

Al-Usman, M. (2008). Panduan Wakaf, Hibah, dan Wasiat Menurut alQur"an dan as-Sunnah, Jakarta:Pustaka Imam Syafi‘I.

Su'ud, M. A. (1997). Risalah fi Jawazi Waqf al-Nuqud. Bairut: Dar Ibn Hazm.

Anshori, A. G. (2006). Perkembangan Hukum Perbankan di Indonesia, Makalah pada kuliah perdana mahasiswa MKn UGM, dalam Kapita Selekta Perbankan Syariah di Indonesia, Yogyakarta: UII Press.

Antonio, S. (2004). Cash Waqf dan Anggaran Pendidikan, dalam Kumpulan Hasil Seminar Perwakafan, Jakarta: Depag RI.

. (2012). Peran Intermediasi Sosial Perbankan Syariah Pelayanan Keuangan Bagi Masyarakat Miskin. Jurnal Keuangan dan Perbankan, Vol.16, No.2 Mei, 2012.

Arif, S. (2010). Wakaf Tunai, Jurnal La Riba Ekonomi Islam, Vol.IV, No.1 Juli, ,Yogyakarta: UII.

Az-Zuhaili, W. (1985). al-Fiqh al-Islami wa Adillatuh Beirut: Dar al-Fikr.

Capra. M. U. dkk. (2002). Corporate Governance In Islamic Financial Institution, Jedah: Ocasional Paper IDB.

Departemen Agama RI. (2006). Peraturan Perundangan Perwakafan. Jakarta: Depag RI. . (2007). Fiqih Wakaf, Jakarta: Direktorat Wakaf Depag RI. 
TAHKIM, Jurnal Peradaban dan Hukum Islam. Vol.1 No.2 (0ktober, 2018) ISSN : 2597-7962

Direktorat Pemberdayaan Wakaf. (2008). Strategi Pengembangan Wakaf Tunai di Indonesia. Jakarta: Dir. Pemberdayaan Wakaf Departemen Agama.

Djunaidi, A. dkk. (2005). Menuju Era Wakaf Produktif : sebuah Upaya Progresif untuk Kesejahteraan Umat. Bandung: Mitra Abadi Press.

Edwin, M. dkk. (2001). Wakaf Tunai Inovasi Finansial Islam, Peluang dan Tantangan dalam Mewujudkan Kesejahteraan Umat . Jakarta: PSTTI-UI.

Furqon, A. (2012). Praktek Wakaf Tunai di Bank Syariah Mandiri, Jurnal Manahij (Jurnal Kajian Hukum Islam), Vol. IV No. 1 Januari.

Ghofur, A. (2006). Hukum dan Praktik Perwakafan di Indonesia, Yogyakarta : Pilar Media.

Halim, A. (2005). Hukum Perwakafan di Indonesia. Jakarta: Ciputat Press.

Mannan. M.A. t.th. Sertifikat Waqf Tunai, sebuah Inovasi Instrumen Keuangan Islam, CIBER bekerjasama dengan PKTTI-UI.

Muslim. T.th. Shahih Muslim, Mesir: Dar al-Fikr al-Mu'ashir.

Muhammad, A. S. (1997). Risalah fi Jawazi Waqf al- Nuqud, Beirut: Dar Ibn Hazm.

Robinson, M. S. (1993). Beberapa Strategi Yang Berhasil Untuk Mengembangkan Bank Pedesaan: Pengalaman Dengan Bank Rakyat Indonesia (BRI) 1970-1990 , Jakarta: Institut Bankir Indonesia.

Rusydiana, A. S. (2008). Mencandera Industri Perbankan Syariah Indonesia: Tinjauan Kritis Pasca UU 21 Tahun 2008, Jurnal Ekonomi Islam La Riba, Vol. II, No. 2, Desember .

Sari, E. K. (2006). Pengantar Hukum Zakat dan Wakaf. Jakarta: Grasindo.

Sinungan, M. (1987). Uang Dan Bank, Jakarta : Bina Aksara.

Soemitra, A. (2010). Bank \& Lembaga Keuangan Syariah. Jakarta: Kencana.

Sulistiani, S. L. (2017). Pembaruan Hukum Wakaf di Indonesia. Bandung: Refika Aditama. 2017. . (2018). Perbandingan Sumber Hukum Islam. Bandung: Jurnal Tahkim Vol.1 No.1 Maret 2018.

Susanto, B. (2008). Hukum Perbankan Syariah Di Indonesia, Yogyakarta: UII Press. 
TAHKIM, Jurnal Peradaban dan Hukum Islam. Vol.1 No.2 (0ktober, 2018) | ISSN : 2597-7962

Zahrah, A, (1971). Muhadharat Fi Al-Waqf, Beirut: Dar Al-Fikr Al-`Arabi, Website:

Farouk. Peri Umar, Sejarah Hukum Perbankan Syariah Indonesia, Dikutip Dari Http://Www.Sharialearn.Com/ diakses 19 November 2016.

Republika, Jum'at, 01 Oktober 2004, "Pengelolaan Wakaf Tunai Hanya Oleh Lembaga Keuangan Syariah".

www.antaranews.com. Diakses 20 April 2017, 20.00 wib.

https://www.dream.co.id/dinar/bni-syariah-himpun-rp27-m-dana-wakaf-161221n.html. Diakses 10 April 2017, 08.00 wib. 